\title{
Effects of Salinity Stress on Emergence and Seedling Growth Parameters of Some Maize Genotypes (Zea mays L.)
}

\author{
Ömer Konuşkan*, Hüseyin Gözübenli, İbrahim Atiş, Mehmet Atak
}

Department of Field Crops, Faculty of Agriculture, Mustafa Kemal University, 31034 Hatay, Turkey

\section{A R T I C LE IN F O}

\section{Research Article}

Received 25 October 2017

Accepted 18 November 2017

Keywords:

Maize

Emergence index

Salt index

Root dry weight

*Corresponding Author:

E-mail: okonuskan@mku.edu.tr
Seedling dry weight

A B S T R A C T

\begin{abstract}
Maize is a very important cereal all over the world and generally cultivated in irrigated agricultural areas. Salinity affects adversely maize productivity in these areas. Maize is known as a salt sensitive species. The salt tolerance level identification in the large genetic resources and breeding populations is an important research topic for solving the salinity problem. The effects of $\mathrm{NaCl}$ stress on germination and seedling growth of fifteen maize genotypes were investigated in this study. Electrical conductivity (EC) values of the $\mathrm{NaCl}$ were settled 0 (distilled water), 4, 6, 8, 10 and $12 \mathrm{dS} \mathrm{m}^{-1}$. This investigation was performed as factorial arrangement of completely randomized design with four replications. Analysis of variance (ANOVA) showed that genotypes, salinity levels and interaction between genotype $\mathrm{x}$ salinity were significant for all the investigated treatments emergence index (EI), root dry weight (RDW), shoot dry weight (SDW), root length (RL), shoot length (SL), and salt tolerance indexes (STI). Results also revealed that the highest reduction in emergence index $(59.7 \%)$ were obtained in the highest level (12 dS $\mathrm{m}^{-1}$ ) of salinity. The results further revealed that the cultivars named DKC 6589 , PR31G98, and PR31A34 were the most tolerant genotypes than the others under NaCI stress.
\end{abstract}

DOI: https://doi.org/10.24925/turjaf.v5i12.1668-1672.1664

\section{Introduction}

Maize (Zea mays L.) is one of the most important crops with high income per unit area within cereals (Shaw, 1988), which is adapted to different climates in the world. Maize production areas are about 165 million hectares, production quantities are about 850 million tons and the average grain yield is about $5200 \mathrm{~kg} \mathrm{ha}^{-1}$ (FAO, 2016). In Turkey, the average annual maize production areas are about 600.000 hectares and productions are about 4.5 million tons with the average grain yield is 7500 $\mathrm{kg} \mathrm{ha}^{-1}$ (TUIK, 2016).

The amount of salt contaminated soils in the world and our country are increasing day by day resulting in a reduction in the yield. In fact, some areas are completely out of maize production due to excessive salinity. There is a salinity problem in $20 \%$ of the total arable land, on the earth (Chinnusamy et al., 2005). Meanwhile, there are about 1.5 million hectares with salinity and alkalinity problems in Turkey (Sönmez, 2004).

Maize planting areas and irrigation potential have increased and consequently total production and yield have increased significantly. Nevertheless, increases in irrigated areas, may have led to salinity problems in maize growing areas.

Salinity is an important stress factor in arid and semiarid regions, particularly, irrigated with saline water and fertilized excessively. It is necessary to improve salt tolerant crops for sustainable food production.

The screening of salt tolerant cultivars has been attempted by many researchers on various species at seedling growth stage of crops (Eker et al., 2006; Carpıc1 et al., 2009; Kökten et al., 2010). Some differences were indicated in salinity responses between plant species (Akgun et al., 2011, Atis, 2011, Kökten et al., 2010). Although salt stress affects all plant growth stages, seed germination and seedling growth stages are known to be more sensitive in most plant species (Ashraf, 1994; Munns, 2002; Cuartero et al., 2006). Seed germination is a major factor limiting the establishment of plant under saline condition. These conditions may cause significant reductions in the rate and percentage of germination. Numerous studies were carried out to determine the salinity effects on seed germination and seedling growth (Eker et al., 2006). Determination of salt-tolerant genotypes during germination and seedling growth period is very important (Atak et al., 2006; Akgün et al., 2011). Çarpicı et al. (2010) indicated that the salt tolerance index was a dependable criteria for salinity resistance in early growth stages of maize. Tayyaba et al. (2010) defined that maize was more sensitive to salt stress in germination stage than latter growth stages. 
This study was conducted to determine salt stress response of some maize cultivars to different salinity levels in early growth stages. Seedling growth characteristics and salt tolerance index were determined.

\section{Material and Methods}

This study was carried out in the greenhouse of Mustafa Kemal University, Agricultural Faculty, Field Crops Department, Hatay/Turkey. Seeds of fifteen maize cultivars (PG 1610, PG 1661, PR31A34, BC-6661, Pasha, OSSK 602, PR31P41, 89MAY70, HELEN, PR31G98, DKC 6876, Tarex 713, BC 678, PR31D24 and DKC6589) were used as a plant material. These cultivars' responses to salinity stress in seedling growth period are not well known. Twenty five seeds were sown in 2 litter pots filled with $1080 \mathrm{~g}$ field soil. Soil was clayey-loamy, mild alkaline without salt, organic matter was low (1.5\%) soil structure (Demir and Konuskan, 2016). Salinity levels of soils in pots were adjusted to control, 4, 6, 8, 10, $12 \mathrm{EC}$ $\mathrm{dS} \mathrm{m} \mathrm{m}^{-1}$ by using $0,0.5994 \mathrm{~g}, 1.3964 \mathrm{~g}, 2.1935 \mathrm{~g}, 2.9935$, $3.7876 \mathrm{~g} \mathrm{NaCl}$ per pot dissolved in $125 \mathrm{ml}$ distilled water, respectively. These doses were chosen previous study results (Köşkeroğlu, 2006). An experiment was settled on 18 June 2012.

All pots were weighted daily and water losses were added using distilled water. Total 5 irrigations were performed. The second irrigation was in 20 of June and $125 \mathrm{ml}$ distilled water was added for each pot. The third irrigation was in 22 of June and $75 \mathrm{ml}$ distilled water was added for each pot. The forth irrigation was in 23 of June and $100 \mathrm{ml}$ distilled water applied for $0,4,6 \mathrm{dS} \mathrm{m}^{-1}, 80$ $\mathrm{ml}$ distilled water applied for $8 \mathrm{dS} \mathrm{m}^{-1}, 10 \mathrm{dS} \mathrm{m}^{-1}$ and 12 $\mathrm{dS} \mathrm{m} \mathrm{m}^{-1}$, respectively. The last irrigation was in 25 of June and pots were irrigated $130 \mathrm{ml}$ distilled water for $0 \mathrm{dS} \mathrm{m} \mathrm{m}^{-1}$ and $4 \mathrm{dS} \mathrm{m}^{-1}, 100 \mathrm{ml}$ for $6 \mathrm{dS} \mathrm{m} \mathrm{m}^{-1}, 80 \mathrm{ml}^{\text {for }} 8 \mathrm{dS} \mathrm{m}^{-1}$ and $50 \mathrm{ml} 10$ and $12 \mathrm{dS} \mathrm{m}^{-1}$. Mean air temperatures of the pots environment during the experiment were $25 \pm 5^{\circ} \mathrm{C}$.

Emergence index, root length, shoot length, root dry weight, shoot dry weight, salt tolerance index were determined as follows:

$$
\text { Emergence index }(\mathrm{EI})=\sum(\mathrm{Gt} / \mathrm{Tt})
$$

Where Gt is the number of seeds germinated on $\mathrm{t}^{\text {th }}$ day and $\mathrm{Tt}$ is the number of days up to $\mathrm{t}^{\text {th }}$ day (Çarpicı et al. 2009).

\section{Salt tolerance index $(\mathrm{STI})=\left(\mathrm{TDW}\right.$ at $\mathrm{S}_{\mathrm{x}} / \mathrm{TDW}$ at $\left.\mathrm{S}_{0}\right) \times 100$}

Where TDW is the total dry weight, $\mathrm{S}_{0}$ is the control and $S_{x}$ is a given concentration of six salinity levels.

15 days old seedlings were harvested and washed in tap water. Seedlings were dried with paper towels. Shoot length (SL) and root length (RL) were measured. Then, the samples were placed in oven for dry weights. The samples were dried at $70^{\circ} \mathrm{C}$ for 48 hours and then shoot dry weight (SDW) and root dry weight (RDW) were determined by a scale with precision $0.0001 \mathrm{~g}$.

The experimental design was a factorial arrangement in Randomized Complete Design with four replications. Analyses of variance of recorded data were performed using the SPSS 14.0 for windows and treatment means were separated by Duncan multiple range test at $\mathrm{P} \leq 0.05$.

\section{Results and Discussions}

\section{Emergence Index}

Genotypes were significant in terms of emergence index (EI) and the highest EI (4.01) was identified on the cultivar PR31A34. This genotype was followed by PR31D24 (3.97), DKC 6589 (3.96), BC-6661 (3.94) and DKC 6876 (3.86) and these cultivars were in the same statistical group with PR31A34. The lowest EI (3.21) was in the Pasha cultivar (Table 1). Maize genotypes showed different responses to salinity stress (Vahid, 2001; Çarpıcı et al. 2009). Seed tolerance to increased salinity during germination is crucial for plant survival in the field, consequently for its further development and high yield performance.

The effect of different salt concentrations on emergence index (EI) was statistically significant and the highest EI (4.63) was determined in control treatment (Table 2). Depending on the increases in salt concentrations, emergence index decreased significantly. It depends on delay of germination and emergence due to increases in osmotic stress of the seed environment with increases in salinity levels (Janmohommadi et al., 2008). Consistent with these results, some researchers have also reported that germination was delayed and decreased due to increased salinity stress in some other crops (Gulzar et al., 2001; Atak et al., 2006; Çarpıcı et al., 2009; 2010).

Considering all the results, it was determined that increased salinity levels affected the emergence of maize varieties negatively, but among the varieties, PR31A34, PR31D24, DKC 6589, BC-6661 and DKC 6876 had better emergence performances than the others by increasing salinity levels.

\section{Root Dry Weight}

Maize genotypes had significantly differences in terms of root dry weight (RDW). The lowest RDW (81.45 mg) was found in genotype DKC6876. This genotype was in the same statistical group with PG1610, Pasha, OSSK 602, DKC6589 and PG-1661. The highest root dry weight (119.08 mg) was determined at genotype of PR31A34. RDW values obtained from PR31A34 and PR31D24 genotypes were higher than the other genotypes. It has also been reported by Carpici et al. (2009) that maize genotypes under salt stress showed significant differences depending on the varieties.

Maize genotypes were also affected with increases in salinity levels. However, RDW value recorded at the lowest salinity ( $4 \mathrm{dS} \mathrm{m}^{-1}$ ) was in the same statistical group with control. The highest RDW were determined in $4 \mathrm{dS}$ $\mathrm{m}^{-1}$ (115.53 mg) and control (115.13 mg) applications. As the salinity levels increased upwards from $6 \mathrm{dS} \mathrm{m}^{-1}$, the RDW tended to decrease significantly in comparison with control and $4 \mathrm{dS} \mathrm{m}^{-1}$. RDW of genotypes at $6,8,10$ and $12 \mathrm{dS} \mathrm{m} \mathrm{m}^{-1}$ were less $10.77 \%, 20.13 \%$ and $58.71 \%$, in comparison with control, respectively. Similar results in RDW values were reported by Carpici et al. (2009).

\section{Shoot Dry Weight}

The effect of genotype and salt concentration were significant in terms of shoot dry weight (SDW). The highest SDW (93.23 mg) was determined in the genotype PR31A34 and the lowest SDW (63.06 mg) in DKC6589 
maize genotype. When the salinity levels increased, shoot dry weights decreased significantly. SDW values of genotypes were changed from $35.58 \mathrm{mg} /$ plant to 94.94 $\mathrm{mg} /$ plant. Reduction rates of genotypes' SDW at $4,6,8$, 10 and $12 \mathrm{dS} \mathrm{m}^{-1}$ salinity levels were $3.63 \%, 6.5 \%$, $6.63 \%, 19.75 \%$ and $62.52 \%$, respectively in comparison with control. Reductions of SDW values were slow up to10 $\mathrm{dS} \mathrm{m}^{-1}$ but drastic at $12 \mathrm{dS} \mathrm{m}^{-1}$. In consistence with our results, Hussein et al. (2007) and Carpici et al. (2009) confirmed that significant decreases in vegetative growth of maize were observed as the salinity levels increased.

\section{Root Length}

The responses of the genotypes to salinity levels for root length (RL) varied significantly. While the longest roots were determined in HELEN $(19.81 \mathrm{~cm})$ and Pasha $(19.13 \mathrm{~cm})$ cultivars, the shortest roots were in PR31A34 $(15.53 \mathrm{~cm})$ maize cultivar. It has also been reported by Khodarahmpour et al. (2012) that root lengths of different maize genotypes showed significant differences in different salinity levels.

Increased $\mathrm{NaCI}$ concentrations caused a remarkable decrease in RL of genotypes. The longest RL $(21.08 \mathrm{~cm})$ were measured in the control and the shortest RL $(9.28$ $\mathrm{cm}$ ) was measured in the highest salinity level applications. Increase in the salinity level to $4 \mathrm{dS} \mathrm{m}^{-1} \mathrm{did}$ not cause a significant decrease in root length compared to the control. As the salinity levels increased to $6 \mathrm{dS} \mathrm{m}{ }^{-1}$, the root length tended to decrease significantly compared to the control, and the root lengths decreased to $5.46 \%$, $10.63 \%, 16.50 \%$ and $55.98 \%$ at $6,8,10$ and $12 \mathrm{dS} \mathrm{m}^{-1}$, respectively. Increase in salinity level from $10 \mathrm{dS} \mathrm{m}^{-1}$ to $12 \mathrm{dS} \mathrm{m}^{-1}$ caused a much severe reduction in root length. The decreasing trend of root length due to increasing salt stress was similar with the reports of previous research results (Köşkeroğlu, 2006).

The length of root is an important characteristic for stress conditions owing to absorb water and nutrients from soil environment. For this reason, the length of roots ensures main clue to response of plants to salinity stress (Khodarahmpour et al., 2012).

These result confirmed that, HELEN and Pasha cultivars which can develop longer roots in the early development period, may be more advantageous in reaching the water and nutrient resources in the salt stress environment (Table 1).

\section{Shoot Length}

Genotypic differences were significant regarding to shoot length (SL). The highest SL was measured with PG $1610(14.08 \mathrm{~cm})$ maize genotype. It was followed by OSSK 602, PR31P41 and PR31A34 and the shortest SL value was observed at DKC $6589(11.62 \mathrm{~cm})$. Differences in shoot lengths of maize genotypes at different salinity levels were also reported by Khodarahmpour et al. (2012).

Table 1 Means values for emergence index (EI), root dry weight (RDW), shoot dry weight (SDW), root length (RL), shoot length (SL) and salt tolerance index (STI) of maize cultivars

\begin{tabular}{l|cccccc}
\hline \multicolumn{1}{c}{ Cultivars } & EI & RDW $(\mathrm{mg} /$ plant $)$ & SDW $(\mathrm{mg} / \mathrm{plant})$ & RL $(\mathrm{cm})$ & SL $(\mathrm{cm})$ & STI $(\%)$ \\
\hline PG 1610 & $3.54^{\mathrm{f}}$ & $83.32^{\mathrm{f}}$ & $76.57^{\mathrm{c}}$ & $18.17^{\mathrm{b}-\mathrm{e}}$ & $14.08^{\mathrm{a}}$ & $77.33^{\mathrm{g}}$ \\
PG 1661 & $3.80^{\mathrm{b}-\mathrm{e}}$ & $86.73^{\mathrm{f}}$ & $68.16^{\mathrm{d}}$ & $18.83^{\mathrm{bc}}$ & $12.52^{\mathrm{d}}$ & $84.39^{\mathrm{c}-\mathrm{e}}$ \\
PR31A34 & $4.01^{\mathrm{a}}$ & $119.08^{\mathrm{a}}$ & $93.23^{\mathrm{a}}$ & $15.53^{\mathrm{g}}$ & $13.60^{\mathrm{ab}}$ & $87.95^{\mathrm{a}-\mathrm{c}}$ \\
BC-6661 & $3.94^{\mathrm{a}-\mathrm{d}}$ & $100.08^{\mathrm{d}}$ & $75.05^{\mathrm{c}}$ & $18.60^{\mathrm{bc}}$ & $13.47^{\mathrm{a}-\mathrm{c}}$ & $86.62^{\mathrm{b}-\mathrm{d}}$ \\
Pasha & $3.21^{\mathrm{g}}$ & $84.43^{\mathrm{f}}$ & $77.72^{\mathrm{c}}$ & $19.13^{\mathrm{ab}}$ & $13.45^{\mathrm{a}-\mathrm{c}}$ & $80.97^{\mathrm{e}-\mathrm{g}}$ \\
OSSK 602 & $3.54^{\mathrm{f}}$ & $85.94^{\mathrm{f}}$ & $74.77^{\mathrm{c}}$ & $18.37^{\mathrm{b}-\mathrm{d}}$ & $13.95^{\mathrm{a}}$ & $80.93^{\mathrm{e}-\mathrm{g}}$ \\
PR31P41 & $3.73^{\mathrm{e}}$ & $100.64^{\mathrm{d}}$ & $87.22^{\mathrm{b}}$ & $17.35^{\mathrm{ef}}$ & $13.85^{\mathrm{a}}$ & $82.30^{\mathrm{d}-\mathrm{f}}$ \\
89MAY70 & $3.81^{\mathrm{b}-\mathrm{e}}$ & $112.29^{\mathrm{bc}}$ & $87.88^{\mathrm{b}}$ & $18.45^{\mathrm{bc}}$ & $12.91^{\mathrm{cd}}$ & $77.73^{\mathrm{fg}}$ \\
HELEN & $3.68^{\mathrm{ef}}$ & $92.68^{\mathrm{e}}$ & $73.99^{\mathrm{c}}$ & $19.81^{\mathrm{a}}$ & $13.56^{\mathrm{a}-\mathrm{c}}$ & $80.07^{\mathrm{e}-\mathrm{g}}$ \\
PR31G98 & $3.754^{\mathrm{de}}$ & $109.33^{\mathrm{c}}$ & $86.65^{\mathrm{b}}$ & $16.72^{\mathrm{f}}$ & $13.46^{\mathrm{a}-\mathrm{c}}$ & $89.21^{\mathrm{ab}}$ \\
DKC 6876 & $3.86^{\mathrm{a}-\mathrm{e}}$ & $81.45^{\mathrm{f}}$ & $65.27^{\mathrm{de}}$ & $17.25^{\mathrm{ef}}$ & $12.45^{\mathrm{d}}$ & $83.10^{\mathrm{de}}$ \\
Tareks 713 & $3.68^{\mathrm{ef}}$ & $98.69^{\mathrm{d}}$ & $74.97^{\mathrm{c}}$ & $18.05^{\mathrm{c}-\mathrm{e}}$ & $12.75^{\mathrm{d}}$ & $80.00^{\mathrm{e}-\mathrm{f}}$ \\
BC -678 & $3.77^{\mathrm{c}-\mathrm{e}}$ & $100.74^{\mathrm{d}}$ & $74.13^{\mathrm{c}}$ & $18.06^{\mathrm{c}-\mathrm{e}}$ & $12.89^{\mathrm{cd}}$ & $83.57^{\mathrm{c}-\mathrm{e}}$ \\
PR31D24 & $3.97^{\mathrm{ab}}$ & $115.10^{\mathrm{ab}}$ & $87.68^{\mathrm{b}}$ & $16.90^{\mathrm{f}}$ & $13.02^{\mathrm{b}-\mathrm{d}}$ & $84.62^{\mathrm{c}-\mathrm{e}}$ \\
DKC 6589 & $3.96^{\mathrm{a}}$ & $81.86^{\mathrm{f}}$ & $63.06^{\mathrm{e}}$ & $17.47^{\mathrm{d}-\mathrm{f}}$ & $11.62^{\mathrm{e}}$ & $91.45^{\mathrm{a}}$ \\
LSD (5\%) & 0.17 & 5.30 & 4.22 & 0.88 & 0.59 & 4.19 \\
CV (\%) & 7.80 & 9.51 & 9.44 & 8.42 & 7.81 & 8.74 \\
\hline
\end{tabular}

*Different letters represent significant differences within a column (Duncan test $\mathrm{P} \leq 0.05$ ).

Table 2 Means of Emergence index (EI), root dry weight (RDW), seedling dry weight (SDW), root length (RL), seedling length (SL) and salt tolerance index (STI) in $\mathrm{NaCl}$ dosages

\begin{tabular}{|c|c|c|c|c|c|c|}
\hline $\mathrm{EC}\left(\mathrm{dS} \mathrm{m^{-1 } )}\right.$ & EI & RDW (mg/plant) & SDW (mg/plant) & $\mathrm{RL}(\mathrm{cm})$ & $\mathrm{SL}(\mathrm{cm})$ & STI \\
\hline 0 & $4.63^{a}$ & $115.13^{\mathrm{a}}$ & $94.94^{\mathrm{a}}$ & $21.08^{\mathrm{a}}$ & $15.50^{\mathrm{a}}$ & $100.0^{\mathrm{a}}$ \\
\hline 4 & $4.45^{\mathrm{b}}$ & $115.53^{\mathrm{a}}$ & $91.49^{\mathrm{b}}$ & $20.76^{\mathrm{a}}$ & $15.14^{\mathrm{ab}}$ & $98.9^{\mathrm{a}}$ \\
\hline 6 & $4.29^{c}$ & $108.08^{b}$ & $88.68^{c}$ & $19.93^{\mathrm{b}}$ & $14.90^{\mathrm{b}}$ & $94.2^{\mathrm{b}}$ \\
\hline 8 & $4.14^{\mathrm{d}}$ & $102.73^{c}$ & $79.62^{\mathrm{d}}$ & $18.84^{\mathrm{c}}$ & $13.51^{\mathrm{c}}$ & $87.1^{\mathrm{c}}$ \\
\hline 10 & $3.69^{\mathrm{e}}$ & $91.95^{\mathrm{d}}$ & $76.19^{\mathrm{e}}$ & $17.60^{\mathrm{d}}$ & $13.11^{\mathrm{d}}$ & $79.7^{\mathrm{d}}$ \\
\hline \multirow[t]{2}{*}{12} & $1.27^{\mathrm{f}}$ & $47.54^{\mathrm{e}}$ & $35.58^{\mathrm{f}}$ & $9.28^{\mathrm{e}}$ & $6.85^{\mathrm{e}}$ & $40.3^{\mathrm{e}}$ \\
\hline & LSD:0.15 & LSD:3.35 & LSD:2.67 & LSD:0.55 & LSD:3.37 & LSD:2.65 \\
\hline
\end{tabular}

*Different letters represent significant differences within a column (Duncan test $\mathrm{P} \leq 0.05$ ). 
The shoot lengths have also been observed to be shortened due to increases in salinity levels. The longest SL (15.50 cm, average) was measured in control treatments while the shortest SL $(6.85 \mathrm{~cm}$, average) was measured in the highest salinity level. Decrease in shoot length is a common situation of many crops exposed salinity stress because of water deficiency or salinity toxicity (Vahid, 2001; Karadavut, 2002). It was well known that decreasing seedling length of crops in salinity stress (Khodarahmpour et al., 2012). The reason for this reduction is the result of water uptake limitation in stress conditions during germination and emergence.

The first measurable effect in cell level is reduction of cell enlargement in water stress that resulting slowdown of seedling development (Kramer, 1974). This unfavorable effect of water stress resulted in $55.8 \% \mathrm{SL}$ reduction in $12 \mathrm{ds} \mathrm{m}^{-1}$ as compared to control. The rates of SL reductions were less at the lower salinity levels of 6,8 , and $10 \mathrm{dS} \mathrm{m}^{-1}$ in comparison with the control.

\section{Salt Tolerance Index}

Salt tolerance indexes (STI) were commonly higher in the lower salinity levels while lower in increased salinity levels. When considering genotypes, the highest STI (91.45) was found in DKC 6589 and the lowest STI (77.33) was determined in PG1610 (Table 1). However, PR31G98 and PR31A34 cultivars were also in the same statistical group with DK 6589 cultivar with regard to STI. Salt tolerance index is a function of both germination rate and total dry weights; therefore, it is a more useful selection criterion. Highest STI values shows the highest salinity tolerance of genotypes (Jaradat et al., 2004). Highest STI indices were observed in cultivars namely DKC 6589, PR31G98 and PR31A34. These cultivars with better agronomic performance and highest STI were recomended for salinity stressed environment during germination and seedling growth of maize.

These results confirmed that these maize cultivars were the salt tolerant genotypes at the germination and seedling growth stages.

Salinity effects on germination and seedling growth stage of maize is an important environmental stress factor determining yield. It is very important to select salt tolerant genotypes during germination and seedling growth for further plant growth and yield.

The salt tolerance index decreased significantly while salinity levels increased as in the other investigated characteristics. Çarpıcı et al. (2009) and Kökten et al. (201) reported that salt tolerant index was decreased as the salt concentration increased. Salt tolerance index values were $98.88 \%$ in $4 \mathrm{dS} \mathrm{m} \mathrm{m}^{-1}, 94.18 \%$ in $6 \mathrm{dS} \mathrm{m}^{-1}$, $87.07 \%$ in $8 \mathrm{dS} \mathrm{m}^{-1}, 79.67 \%$ in $10 \mathrm{dS} \mathrm{m}^{-1}$ and $40.29 \%$ in $12 \mathrm{dS} \mathrm{m}^{-1}$, respectively.

\section{Conclusion}

In this study, it was determined that the salinity levels in the soil environment were at different boundary values for each genotype, and the investigated characteristics of maize genotypes were significantly affected by the increasing salinity levels.

Our findings showed that the maize genotypes used in the experiment reacted differently to the salinity levels of soil and the salt content was also a significant limiting factor in the soil, beside the low salt concentrations in the germination period of the plant had a positive effect on the germination. Our result concluded that DKC 6589, PR31G98 and PR31A34 were more tolerant maize genotypes to salinity.

\section{References}

Asraf M. 1994. Breeding for Salinity Tolerance in Plants. Critical Reviews in Plant Sciences, 13(1): 17-42.

Atak M, Kaya MD, Kaya G, Çikili Y, Çiftçi CY. 2006 Effects of $\mathrm{NaCl}$ on the Germination, Seedling Growth and Water Uptake of Triticale. Turk. J. Agric. For., 30: 39-47.

Atı̧ I. 2011. Bazı Silajlık Sorgum (Sorghum bicolor L. Moench) Çeşitlerinin Çimlenmesi ve Fide Gelişimi Üzerine Tuz Stresinin Etkileri. Süleyman Demirel Üniversitesi Ziraat Fakültesi Dergisi 6 (2): 58-67

Akgün I, Kara B, Altındal D. 2011. Effect of Salinity (Nacl) On Germination, Seedling Growth and Nutrient Uptake Of Different Triticale Genotypes, Turkish Journal of Field Crops, 16 (2): $225-232$

Carpıc1 E, Celik BN, Bayram G. 2009. Effects of Salt Stress on Germination of Some Maize (Zea mays L.) Cultivars. African Journal of Biotechnology Vol. 8 (19): 4918-4922.

Çarpıcı E, Çelik B, Bayram NG, Asik B. 2010. The Effects of Salt Stress on Growth, Biochemical Parameter and Minaral Element Content of Maize (Zea mays L.) Cultivars. African Journal of Biotechnology Vol. 9 (41): 6937-6942.

Chinnusamy V, Jagendorf A, Zhu, J-K. 2005. Understanding and Improving Salt Tolerance in Plants. Crop Science 35: 437-448.

Cuartero J, Bolarin MC, Asins MJ, Moreno V. 2006. Increasing salt tolerance in Tomato. J. Exp. Bot. 57: 1045-1058.

Demir E, Konuşkan Ö. 2016. Çukurova Koşullarında Bazı Atdişi Mısır Genotiplerinin Performanslarının Belirlenmesi. Süleyman Demirel Üniversitesi Ziraat Fakültesi Dergisi 11 (2): 11-20,

Eker S, Cömertpay G, Konuşkan Ö, Ülger AC, Öztürk L, Çakmak. I. 2006. Effect of Salinity on Dry Matter Production and Ion Accumulation in Hybrid Maize Varieties. Turk. J. Agric. For., 30: $365-373$

FAO. 2016. http://www.fao.org/statistics/en/

Gulzar S, Khan MA, Ungar IA. 2001. Effect of Salinity and Temperature on the Germination of Urochongra setulosa (Trin.) C.E. Hubbard. Seed Sci. Technol., 29: 21- 29.

Hussein MM, Balbaa LK, Gaballah MS. 2007. Salicylic Acid and Salinity Effects on Growth of Maize Plants. Res. J. Agric. Biological Sci. 3(4): 321-328.

Janmohommadi M, Desfuji PM, Sharifzadeh F. 2008. Seed VigorationTechniques to Improve Germination and Early Growth of Inbred Line of Maize under Salinity and Drougth Stress. Gen. Appl. Plant Physiology, (special issue) 34 (3-4): 215-226.

Jaradat AA, Shahid M, Al-Maskri A. 2004. Genetic diversity in the batini barley land race from Oman. II. Response to Salinity Stress. Crop Science, 44: 997-1007

Karadavut S. 2001. Gelişme Döneminde Verilen Farklı Tuz Tipi ve Tuz Konsantrasyonlarının Mısır ve Fasulye Bitkileri Üzerinde Morfolojik Özellikler ve Verime Etkisi. Gebze yüksek Teknoloji Enstitüsü ve Fen Bilimleri Enstitüsü, Biyololi Anabilim dalı Yüksek Lisans Tezi s.81

Khodarahmpour M, Zahra I, Mohammad M. 2012. Effects of $\mathrm{NaCl}$ Salinity on Maize (Zea mays L.) at Germination and Early Seedling Stage. African Journal of Biotechnology11(2): 298304

Kökten K, Karaköy T, Bakoğlu A, Akçura M. 2010. Determination of Salinity Tolerance of Some Lentil (Lens culinaris M.) Varieties. Journal of Food, Agriculture \& Environment, 8(1): 140- 143 .

Köşkeroğlu S. 2006. Tuz ve Su Stresi Altındaki Mısır (Zea mays L.) Bitkisinde Prolin Birikim Düzeyleri ve Stres Parametrelerinib Araştırılması. Muğla Üniversitesi Fen Bilimleri Enstiyüsü Biyoloji Anabilim Dalı Yüksek Lisans Tezi, s.106. 
Kramer PJ. 1974. Fifty Years Of Progress in Water Relations Research. Plant Physiol. 54: 463-471.

Munns R. 2002. Comparative Physiology of Salt and Water Stress. Plant Cell Environ. 5(2): 239-250.

Shaw RH. 1988. Climate Requirement Maize and Maize Improvement. ASA, CSSA, SSSA, 609-638, Wisconsin, USA

Sönmez B. 2004.Türkiye'de Çorak Islahı Araştırmaları ve Tuzlu Toprakların Yönetimi. Sulanan Alanlarda Tuzluluk Yönetimi Sempozyumu Bildiriler Kitab1, 20-21 Mayıs, Ankara, 157-162.

Tayyaba K, Khalid H, Abdul M, Khalid N, Nisar NM. 2010.
Morphological Variations in Maize (Zea mays L.) Under Different Levels of Nacl at Germinating Stage. World Applied Sciences Journal 8 (10): 1294-1297.

TÜiK. 2016. http://www.tuik.gov.tr

Vahid HA. 2001. Response of Maize (Zea mays L.) to Compound Type of Salinity, Pakistan Journal Bot. 33 (Special İssue): 455461. 